\begin{tabular}{|l|l|l||}
\hline \multicolumn{2}{|c|}{ PublisherInfo } \\
\hline \hline PublisherName & $:$ & BioMed Central \\
\hline \hline PublisherLocation & $:$ & London \\
\hline \hline PublisherImprintName & $:$ & BioMed Central \\
\hline \hline
\end{tabular}

\title{
Reverse evolution
}

\begin{tabular}{|l|c|l||}
\hline \multicolumn{2}{|c|}{ ArticleInfo } \\
\hline \hline ArticleID & $:$ & 4715 \\
\hline \hline ArticleDOI & $:$ & $10.1186 /$ gb-spotlight-20030306-02 \\
\hline \hline ArticleCitationID & $:$ & spotlight-20030306-02 \\
\hline \hline ArticleSequenceNumber & $:$ & 67 \\
\hline \hline ArticleCategory & $:$ & Research news \\
\hline ArticleFirstPage & $:$ & 1 \\
\hline \hline ArticleLastPage & $:$ & 2 \\
\hline \hline & & RegistrationDate : 2003-3-6 \\
\hline ArticleHistory & $:$ & OnlineDate \\
\hline \hline ArticleCopyright & $:$ & BioMed Central Ltd2003-3-6 \\
\hline \hline ArticleGrants & $:$ & \\
\hline \hline ArticleContext & $:$ & 130594411 \\
\hline \hline
\end{tabular}


The process of speciation (when one species splits into two distinct species that can no longer mate efficiently) takes thousands of years, and the underlying mechanisms are therefore difficult to investigate in the laboratory. In the March 6 Nature, Delneri et al. describe experiments designed to reverse the process of speciation using genomic engineering in yeast (Nature 2003, 421:952-956). The Saccharomyces 'sensu stricto' yeasts comprise six species and interspecies matings produce sterile hybrids. The S. cerevisiae lab strain HY73 and the S. mikatae natural isolate IFO1816 have similar genomes that differ by a reciprocal chromosomal translocation. Delneri et al. tested the role of this translocation and the importance of genomic collinearity in reproductive isolation. They engineered the HY73 chromosomes so that they resembled those of IFO1816. The rearranged strain could now mate with IFO1816, demonstrating that re-establishing collinearity can reverse the process of speciation and reproductive isolation.

\section{References}

1. Nature, [http://www.nature.com]

2. Chromosomal evolution in Saccharomyces. 